\title{
EFEKTIVITAS TEKNIK REBT DALAM KONSELING TEMAN SEBAYA UNTUK MENGATASI KECEMASAN MATEMATIKA SISWA SMA
}

\author{
Moesarofah \\ FKIP, Universitas PGRI Adi Buana Surabaya \\ Email: moesarofah@unipasby.ac.id
}

\begin{abstract}
Abstrak
Prestasi matematika menjadi prediktor keterlibatan dan keberhasilan akademik siswa, namun tidak semua siswa tertarik dengan matematika. Siswa remaja dengan kecemasan matematika cenderung mengungkapkan permasalahannya pada teman sebaya. Tujuan penelitian untuk mengetahui seberapa efektif pengaruh teknik REBT dalam konseling teman sebaya dalam mengatasi kecemasan matematika siswa SMA. Responden penelitian adalah siswa SMA ITP Surabaya kelas $X$. Jenis penelitian adalah true eksperiment. Populasi penelitian adalah siswa SMA ITP kelas X sejumlah 210 siswa. Pengambilan sampel melalui teknik purposive random sampling. Rancangan penelitian pre-test dan post-test control group design. Pengukuran data menggunakan skala adopsi dari mathematic anxiety scale-revised. Analisa data menggunakan teknik uji paired t-test. Hasil menunjukkan teknik REBT dalam konseling teman sebaya memberi pengaruh efektif dalam mengatasi kecemasan matematika siswa SMA ITP kelas X. Selain itu hasil intervensi menunjukkan kemampuan siswa dalam menemukan nilai-nilai kebermanfaatan dalam pencapaian matematika melalui usaha-usaha solutif yang mengarah pada ketekunan, maupun keterbukaan. Implementasi intervensi diperlukan adanya motivasi diri yang kuat dari siswa untuk berubah, dengan melakukan konfrontasi atas keyakinan irasional yang dialami ke arah yang lebih rasional, serta tetap mempertimbangkan nilai-nilai kebermanfaatan dari pencapaian matematika.
\end{abstract}

Kata kunci: Teknik REBT, Konseling teman sebaya, Kecemasan mathematics

\begin{abstract}
Mathematical achievement is a predictor of student engagement and academic success, but not all students are interested in mathematics. Teenage students with math anxiety tend to express their problems with peers. The purpose of this study was to determine how effective the effect of REBT technique in peer counseling was to overcome the mathematics anxiety of high school students. The research respondents were 10th grade students of ITP Surabaya, total 210 students. Sampling through purposive random sampling technique. The type of research was true experiment, pre-test and post-test control group design. Measurement of data using the adoption scale of the mathematic anxiety scale-revised. Data analysis uses paired t-test test technique. The results showed that REBT technique in peer counseling had an effective influence in overcoming the mathematics anxiety of 10th grade students of ITP Surabaya. Besides the results of the intervention showed the ability of students to find useful values in achieving mathematics through solutive efforts that lead to perseverance, and openness. Implementation of the intervention requires strong self-motivation from students to change, by confronting the irrational beliefs experienced in a more rational direction, while still considering the values of the usefulness of mathematical achievement.
\end{abstract}

Keywords: REBT technique, peer counseling, mathematics anxiety 


\section{PENDAHULUAN}

Secara akademik, prestasi matematika sangat penting bagi siswa SMA. Prestasi matematika sangat mendukung keberhasilan dalam disiplin keilmuan, dan menjadi prediktor keterlibatan dan keberhasilan akademik siswa. Penelitian luas menunjukkan beberapa siswa SMA yang masuk dalam tahap perkembangan remaja cenderung mempertahankan motivasi dan performansinya dalam mata pelajaran matematika, namun sebagian siswa lain memiliki motivasi yang rendah (PriessGroben \& Hyde, 2016). Tidak semua siswa tertarik dengan matematika. Mereka berusaha menghindari, bahkan mengabaikan kompetensi dasar yang disyaratkan dalam keberhasilan matematika. Di SMA ITP Surabaya sekitar 52 dari 210 siswa kelas X $(25 \%)$ merasakan kecemasan dalam mengikuti pelajaran matematika. Dari hasil interview sebagian besar dari mereka beralasan karena metode pengajaran yang kurang dapat diterima siswa.

$\begin{array}{ccc}\text { Saat siswa SMA merasakan } \\ \text { matematika, } & \text { mereka } & \text { cenderung }\end{array}$ mengungkapkan permasalahannya pada teman sebaya daripada orang tua maupun guru. Teman sebaya merupakan faktor yang sangat berpengaruh terhadap kehidupan masa remaja, karena siswa remaja menghabiskan sebagian besar waktunya bersama dengan teman sebaya.

Fakta di atas memperkuat perlunya intervensi yang mempersempit kesenjangan antara siswa yang beruntung dan kurang beruntung dalam prestasi matematika (Watts, Duncan, Siegler, \& Davis-kean, 2015). Selain itu sedikitnya hasil penelitian intervensi dalam menurunkan kecemasan matematika pada siswa SMA, mendorong peneliti untuk mendesain penelitian intervensi tentang konseling teman sebaya dalam menurunkan kecemasan matematika. Konseling teman sebaya merupakan metode dalam modifikasi perilaku, dengan membantu teman sebaya dalam mengubah sikap melalui penguatan belajar dan umpan balik. Karakteristik konselor teman sebaya setidaknya adalah siswa yang secara naluri senang bekerja sama secara kooperatif dan mempunyai kepedulian pada teman lain. Dengan demikian konselor teman sebaya adalah figur model yang berperan positif dalam memberikan pengaruh positif pada teman-teman yang lain (Bett, 2013).

Tujuan penelitian untuk mengetahui seberapa efektif pengaruh teknik Rational Emotive Behavior Therapy (REBT) dalam konseling teman sebaya untuk mengatasi kecemasan matematika siswa SMA. Pertimbangan peneliti menggunakan teknik REBT, karena kecemasan matematika relatif berkaitan dengan cara berpikir yang tidak logis sebagai penyebabnya. Teori berasumsi bahwa suatu perubahan yang mendalam terhadap cara berpikir dapat menghasilkan perubahan yang berarti pada emosi dan perilaku (Corey, 2009; (Dryden, 2006).

Strategi konseling dalam teman sebaya dilakukan, karena karakteristik menonjol pada masa remaja adalah terbentuknya konformitas atau kedekatan remaja dengan teman sebaya yang meningkat secara drastis, dan pada saat bersamaan kedekatan hubungan remaja dengan orang tua menurun drastis (Santrock, 2012). Selain itu besarnya jumlah siswa SMA tidak sebanding dengan jumlah guru BK, sehingga kebutuhan untuk melatih konselor teman sebaya menjadi hal yang penting di SMA.

Responden penelitian adalah siswa SMA Intensif Taruna Pembangunan (ITP) Surabaya kelas $\mathrm{X}$ jurusan IPA dan IPS, dengan pertimbangan siswa kelas $\mathrm{X}$ merupakan siswa tahun pertama yang mengalami masa transisi dalam penyesuaian tuntutan akademik di lingkungan baru. Layaknya siswa baru, siswa kelas X dengan potensi psikologis yang semakin berkembang mandiri daripada siswa SMP diharapkan mampu memotivasi diri dalam mengatur waktu maupun sumber daya yang dimiliki untuk mengarah pada tujuan akademik.

\section{METODE PENELITIAN}

Jenis penelitian ini adalah true eksperiment, yakni rancangan penelitian eksperimen, dengan terpenuhinya tiga unsur eksperimental sesungguhnya yaitu: (1) 
randomisasi, (2) replika dan (3) kelompok kontrol. Populasi penelitian adalah siswa SMA ITP kelas X sejumlah 210 siswa terdiri dari 6 kelas. Pengambilan sampel melalui teknik purposive random sampling dengan batasan penelitian, yakni: siswa yang mengalami kecemasan matematika, dan nilai NEM SMP sekurang-kurangnya 28.00, dan terpilih 52 siswa yang merasa cemas pada mapel matematika.

Selanjutnya dari 52 siswa yang mengalami kecemasan matematika secara random dipilih 20 siswa sebagai responden penelitian, yang terbagi atas: kelompok eksperimen sebanyak 10 orang, dan kelompok kontrol sebanyak 10 orang. Dari 20 responden yang mengalami kecemasan matematika terdiri dari 5 siswa laki-laki, dan 15 siswa perempuan.

Sebelum melakukan intervensi, kepada calon konselor sebaya diberikan pelatihan teknik REBT dalam konseling teman sebaya selama dua kali tatap muka, dengan materi: (1) ketrampilan dasar konseling, (2) penerapan teori ABC. Selanjutnya kepada konseli diberikan treatmen teknik REBT dalam konseling teman sebanya selama lima kali tatap muka, masing-masing dengan durasi 100 menit, mencakup tahapan: (1) rapport, kontrak konseling, (2) tujuan dan harapan proses konseling, (3) identifikasi masalah, \& activating effect, (4) activating effect \& konsekuensi, (5) perubahan keyakinan irasional menjadi rasional. Teknik konseling dilakukan secara role playing, imitasi, dan penugasan.

Definisi operasional variabel penelitian, mencakup: (1) variabel $\mathrm{x}$ : teknik REBT dalam konseling teman sebaya, yaitu pemberian bantuan yang dilakukan oleh seorang siswa yang dilatih sebagai konselor sebaya kepada teman sebaya dalam mengungkapkan kecemasannya yang berasal dari pemikiran-pemikiran irasional, dengan cara membantu mengembalikan ide-ide/ pemikiran ke arah yang lebih rasional, sehingga diharapkan konseli dapat bertanggung jawab untuk menemukan dan memecahkan masalahnya sendiri. variabel y: kecemasan matematika adalah keadaan gugup dan tidak nyaman dalam mengikuti kelas maupun ujian mapel matematika.

Pada kelompok eksperimen, responden diberikan konseling teman sebaya dengan teknik REBT, sementara kelompok kontrol tidak berikan suatu treatmen. Pengukuran pada kelompok eksperimen dan kontrol dilakukan melalui pre-test dan post-test. Rancangan penelitian menggunakan pre-test dan posttest control group design (Zainudin, 2011).

Pengukuran data menggunakan skala yang diadopsi dari Bai (2011) tentang mathematic anxiety scale-revised yang secara psikometri menunjukkan valid dan reliabel. Analisa data menggunakan teknik uji paired t-test, yang bertujuan membandingkan dua kelompok: eksperimen dan kontrol (Gunawan, 2015). Hasil uji paired t-test menunjukkan teknik REBT dalam konseling teman sebaya memberi pengaruh efektif dalam mengatasi kecemasan matematika siswa SMA ITP kelas X.

\section{HASIL DAN PEMBAHASAN}

Sebelum melakukan teknik REBT dalam konseling teman sebaya untuk mengatasi kecemasan matematika siswa SMA, terlebih dahulu peneliti melakukan analisis deskriptif untuk mengetahui gambaran umum dan karakteristik pada masing-masing kelompok, seperti pada tabel berikut:

Tabel .1 Gambaran umum kelompok kontrol

\begin{tabular}{|l|l|l|}
\hline \multirow{2}{*}{ Statistik } & \multicolumn{2}{|l|}{ Kelas Kontrol } \\
\cline { 2 - 3 } & Pre-Test & Post-Test \\
\hline Jumlah responden & 10 & 10 \\
\hline Skor terendah & 22 & 21 \\
\hline Skor tertinggi & 38 & 26 \\
\hline Rata-rata & 26.1 & 23.5 \\
\hline Mean difference & 2.6 \\
\hline
\end{tabular}

Tabel 1 menunjukkan nilai skor rata-rata pada post-test lebih kecil dari pada pre-test $(23.5<26.1)$, maka secara deskriptif tidak 
terdapat kenaikan yang signifikan nilai skor rata-rata antara pre-test dan post-test pada kelompok kontrol. Hasil tersebut bisa dilihat pada grafik berikut

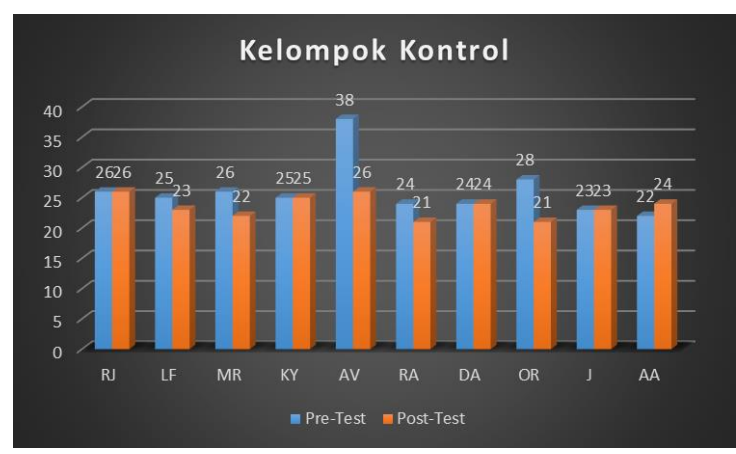

Grafik diatas menunjukkan bahwa terdapat penurunan nilai skor antara pre-test dan posttest pada kelompok kontrol.

Tabel .2 Gambaran umum kelompok eksperimen

\begin{tabular}{|l|l|l|}
\hline \multirow{2}{*}{ Statistik } & \multicolumn{2}{|l|}{ Kelas Eksperimen } \\
\cline { 2 - 3 } & Pre-Test & Post-Test \\
\hline Jumlah data & 10 & 10 \\
\hline Skor terendah & 16 & 38 \\
\hline Skor tertinggi & 28 & 52 \\
\hline Rata-rata & 23.2 & 45.9 \\
\hline Mean difference & 22.7 \\
\hline
\end{tabular}

Tabel .2 menunjukkan nilai skor rata-rata pada post-test lebih besar dari pada pre-test $(45.9>23.2)$ maka secara deskriptif terdapat kenaikan yang signifikan nilai rata-rata skor antara pre-test dan post-test.

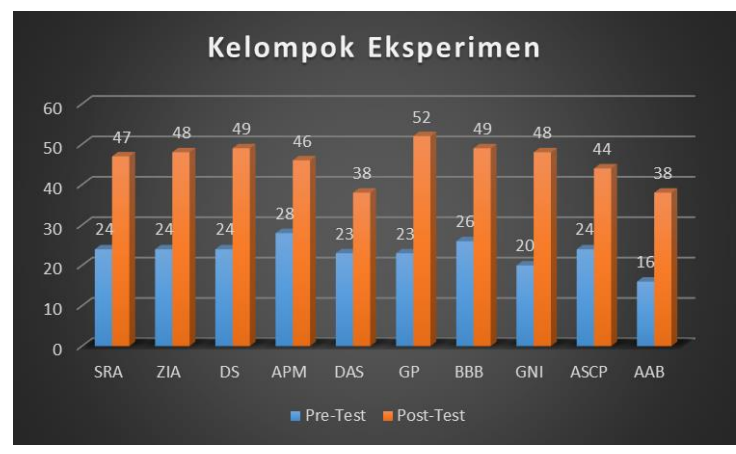

Hasil grafik diatas menunjukkan bahwa terdapat kenaikan yang signifikan antara nilai skor pre-test dan post-test pada kelompok eksperimen.

Pengujian hipotesis dilakukan untuk mengetahui apakah terdapat nilai skor yang signifikan antara pre-test dan post-test pada kelompok masing-masing. Jika terdapat nilai p-value kurang dari 0,05 maka $\mathrm{H}_{0}$ ditolak; dan jika p-value lebih besar dari 0,05 maka $\mathrm{H}_{0}$ diterima. Hasil pengujian dapat dilihat pada tabel berikut

Tabel .3 Hasil pengujian kelompok Kontrol

\begin{tabular}{|l|l|l|l|}
\hline $\begin{array}{l}\text { Kelompok } \\
\text { control }\end{array}$ & $\begin{array}{l}\text { T- } \\
\text { hitung }\end{array}$ & $\begin{array}{l}\text { P- } \\
\text { value }\end{array}$ & Keterangan \\
\hline $\begin{array}{l}\text { Pre-test } \\
\text { dan post } \\
\text { test }\end{array}$ & 1,960 & 0,082 & $\begin{array}{l}\mathrm{H}_{0} \\
\text { diterima }\end{array}$ \\
\hline
\end{tabular}

Bersadarkan hasil pengujian diatas dapat dilihat bahwa nilai p-value yang diperoleh sebesar sebesar 0,082. Karena nilai p-value lebih besar dari 0.05 maka $\mathrm{H}_{0}$ diterima, artinya tidak ada perbedaan yang signifikan antara nilai skor pre-test dan posttest pada kelompok kontrol

Tabel .4 Hasil pengujian kelompok Eksperimen

\begin{tabular}{|l|l|l|l|}
\hline $\begin{array}{l}\text { Kelompok } \\
\text { Eksperime } \\
\mathrm{n}\end{array}$ & $\begin{array}{l}\text { T- } \\
\text { hitung }\end{array}$ & P-value & $\begin{array}{l}\text { Keterang } \\
\text { an }\end{array}$ \\
\hline $\begin{array}{l}\text { Pre-test } \\
\text { dan post- } \\
\text { test }\end{array}$ & $-16,811$ & 0,000 & $\mathrm{H}_{0}$ ditolak \\
\hline
\end{tabular}

Berdasarkan hasil pengujian diatas dapat dilihat bahwa nilai p-value yang diperoleh sebesar sebesar 0,000 . Karena nilai p-value lebih kecil dari 0.05 maka $\mathrm{H}_{0}$ ditolak sehingga disimpulkan bahwa ada perbedaan yang signifikan antara nilai skor pre-test dan post-test pada kelompok eksperimen, artinya Teknik REBT dalam Konseling Teman Sebaya secara efektif dapat mengatasi Kecemasan matematika siswa SMA ITP Surabaya kelas X.

Karakteristik matematika yang bersifat bilangan, logis, memiliki tingkat kesulitan yang semakin bertambah membutuhkan ketekunan, motivasi berprestasi dan usaha yang berkelanjutan dari siswa untuk 
mencapai kompetensi tersebut. Sebaliknya ketika siswa tidak memberikan waktu lebih untuk mempelajari matematika, dan mengabaikan kesulitan yang dialami maka ketidakmampuan tersebut akan berakumulasi yang mengganggu keadaan psikologisnya, termasuk munculnya rasa cemas dan pikiranpikiran negatif berkaitan dengan ketidakmampuannya dalam mengikuti mapel matematika. Selain itu strategi pengajaran guru yang kurang memperhatikan kebutuhan maupun kesulitan siswa, membuat siswa semakin tidak tertarik dengan mapel matematika. Kehadiran emosi negatif ini memicu munculnya pemikiran negatif atau irasional.

Sementara itu efektivitas teknik REBT dalam konseling teman sebaya untuk mengatasi kecemasan matematika berkaitan dengan motivasi diri siswa untuk berubah lebih baik dalam mengatasi kecemasan matematika melalui keterbukaannya dalam menyampaikan kesulitannya pada orang lain, kesediaannya secara sukarela mengikuti suatu treatmen, serta kemauan untuk memperbaiki proses belajar dengan menghadirkan emosi menyenangkan. Misal mengikuti les privat, belajar secara kooperatif, dan menemukan nilai-nilai bermanfaat dari kerja keras belajar matematika.

Melalui teknik REBT dalam konseling teman sebaya, siswa menjadi paham cara mengidentifikasi permasalahan ketika mengalami suatu kesulitan, dan cara menganalisis permasalahan melalui teori ABC, yakni dari keluhan yang dialami berusaha untuk mengidentifikasi peristiwa yang mengawali munculnya suatu keluhan (activating/antesedent event), serta menganalisis konsekuensi dari keyakinan yang terbentuk berkaitan dengan anteseden tersebut, selanjutnya siswa berusaha menemukan keyakinan irasional yang terbentuk dan mengganti dengan keyakinan rasional yang bernilai positif.

\section{KESIMPULAN}

Kecemasan matematika bagi siswa tidak disikapi dengan perilaku menghindar dan menyalahkan orang lain, namun siswa harus dapat melihat nilai-nilai kebermanfaatan dari pencapaian matematika, karena kecemasan yang diabaikan secara akumulatif akan menghambat pemrosesan informasi dan menurunkan self-esteem.

Teknik REBT dalam konseling teman sebaya secara efektiv dapat mengatasi kecemasan matematika siswa, karena dalam REBT siswa belajar memahami cara mengidentifikasi suatu permasalahan, mengenali antesedennya serta konsekuensi dari koping yang dilakukan. Munculnya perubahan dalam cara berpikir berpengaruh pada perubahan perilaku dan emosi siswa dalam mengatasi kecemasan matematika.

\section{REFERENSI}

Bai, H. 2011. Cross-Validating a Bidimensional Mathematics Anxiety Scale. Assessment, 18(1), 115- 122. https://doi.org/10.1177/1073191110364 312.

Bett, J. C. 2013. The Importance of Promoting the Value and the Role of Peer Counseling among Students in Secondary Schools. International Journal of Economy, Management and Social Sciences, 2(June), 477-484.

Corey, G. 2009. Theory and Practice of Counseling and Psychotherapy, 8th. Belmont, California : Brooks/Cole.

Dryden, W., \& Neenan, M. 2006. Rational Emotive Behaviour Therapy: 100 Key Points and Techniques. New York: Routledge.

Gunawan, Muhammad Ali. 2015. Statistik Penelitian Bidang Pendidikan, Psikologi dan Sosial. Cetakan: Pertama. Yogyakarta: Parama Publishing. 
Volume 71, Nomor 2, 1 Desember 2019

Priess-Groben, H. A., \& Hyde, J. S. 2016. Implicit Theories, Expectancies, and Values Predict Mathematics Motivation and Behavior across High School and College. Journal of Youth and Adolescence, $0-1$. https://doi.org/10.1007/s10964-0160579-y.

Santrock, J. W. 2012. Life-Span development:Perkembangan MasaHidup. Jakarta: Erlangga.

Watts, T. W., Duncan, G. J., Siegler, R. S., \& Davis-kean, P. E. 2015. What's Past Is Prologue: Relations Between Early Mathematics Knowledge and High School Achievement, 43(7). https://doi.org/10.3102/0013189X14553 660.

Zainudin, M. 2011. Metodologi Penelitian Kefarmasian dan Kesehatan. Cetakan Pertama. Surabaya: Airlangga University Press. 